ISSN 2006 - 6996

\title{
MARITAL STATUS AND OCCUPATION VERSUS SERUM TOTAL CHOLESTEROL AND HDL - CHOLESTEROL LEVELS IN HEALTHY ADULTS FROM KANO METROPOLIS, NIGERIA
}

\author{
Atiku, M.K. and Yusuf, A.B. \\ Department Of Biochemistry, Bayero University, P.M.B 3011, Kano, Nigeria
}

\begin{abstract}
The influence of marital status and occupation on serum total cholesterol (TC) and high density lipoprotein cholesterol (HDL - CH) concentrations was studied in sixty one (61) adult male and female Hausa subjects aged 20 - 50 years. Irrespective of marital status and occupation, female subjects had higher mean serum TC and HDL - CH levels than male subjects. Married subjects of both sexes had higher mean serum TC and HDL - CH levels than their non - married counterparts. Male subjects (students) had significantly $(p<0.05)$ lower mean serum TC than the other male subjects (university workers).
\end{abstract}

Keywords: Occupation, Cholesterol, Kano, Serum Lipid

\section{INTRODUCTION}

Differences in serum $\mathrm{HDL}-\mathrm{CH}$ and low density lipoprotein cholesterol ( $\mathrm{LDL}-\mathrm{CH}$ ) levels between communities have been employed in explaining the postulated relationship that exist between serum lipoprotein levels and the incidence of coronary heart disease (CHD). Epidemiologic studies (Reddy, 2002) revealed that communities in which incidence of $\mathrm{CHD}$ is low, have low values of $\mathrm{LDL}-\mathrm{CH}$ and high values of $\mathrm{HDL}-\mathrm{CH}$. Factors known to increase the risk of CHD which are primarily due to culture and environment are cigarette smoking (Atiku et al., 2001), dietary habits (Kerver et al., 2003), lack of physical exercise (Lee et al., 2003), occupation (Henry et al., 2003), etc. Therefore, serum lipid and lipoprotein pattern should be interpreted against the socio-economic and cultural backgrounds of individuals or communities at large.

Very little or nothing is known about the variation of serum total cholesterol and HDL cholesterol and HDL - cholesterol levels with occupation and marital status in the Hausa community of Kano State. This study was therefore undertaken to assess the effect of marital status and occupation on serum total cholesterol and $\mathrm{HDL}-\mathrm{CH}$ levels in an adult Nigerian populace. It is hoped that the results of the study would provide a basis for the interpretation of serum total cholesterol and $\mathrm{HDL}-\mathrm{CH}$ profile in the Hausa community of Kano State.

\section{MATERIALS AND METHODS}

\section{Study Sites}

Subjects for this study were adult male and female Hausas resident in Kano Municipality. A total of sixty one subjects (42 males and 19 females) aged 20 to 60 years were selected on the basis of their responses to a randomly administered questionnaire. Forty - four percent of the subjects were students, the remaining fifty six percent were workers of Bayero University, Kano. Informed consent was given by each subject.
Information concerning each respondent's age, marital status, sex and occupation were recorded.

\section{Laboratory Analysis}

Fasting various blood $\left(5 \mathrm{~cm}^{3}\right)$ sample was collected from each subject according to standard procedure (Bachorik, 1982). After serum separation, the samples were stored at $20^{\circ} \mathrm{C}$ until analysed. Serum TC level was estimated according to the ferric chloride acetic cid procedure (Zlatkis et al., 1953). Chylomicrons, very low density lipoproteins (VLDL) and low density lipoproteins (LDL) were precipitated in serum according to the phosphotungstic acid - magnesium chloride procedure of Lopes - Virella et al. (1977), and HDL - cholesterol was measured in the resultant supernatant (Zlatkis et al., 1953).

\section{Statistical Analysis}

Differences in the levels of mean serum TC and HDL $\mathrm{CH}$ amongst the subjects were analyzed using students ' $\mathrm{t}$ ' test.

\section{RESULTS}

Table 1 shows the mean serum total cholesterol and $\mathrm{HDL}$ - cholesterol concentrations in the subjects according to sex. Female subjects had higher mean serum total cholesterol and $\mathrm{HDL}$ - cholesterol levels than male subjects.

Table 2 presents the mean serum total cholesterol and HDL - cholesterol concentrations in the subjects according to marital status and occupation. Irrespective of marital status and occupation, female subjects had higher mean serum total cholesterol and HDL - cholesterol levels than male subjects.

Married male subjects had significantly $(p<0.05)$ higher mean serum total cholesterol than their non married male counterparts. Non - married female subjects had significantly $(p<0.05)$ higher mean serum total cholesterol level than non - married male subjects. 
Male subjects (students) had significantly $(p<0.05)$ lower mean serum total cholesterol level than other male subjects (University workers), while female students had significantly $(p<0.05)$ higher mean serum total cholesterol level than male students.

Table 1: Serum total cholesterol, and high density lipoprotein cholesterol concentrations in subjects according to sex.

\begin{tabular}{lccc}
\hline Subjects & TC $(\mathbf{m g} / \mathbf{d l})$ & HDL $-\mathbf{C H}(\mathbf{m g} / \mathbf{d l})$ & HDL $-\mathbf{C H} / \mathbf{T C}$ \\
\hline Males $(\mathrm{n}=42)$ & $143.15 \pm 34.03$ & $28.04 \pm 12.40$ & 0.19 \\
Females $(\mathrm{n}=19)$ & $162.34 \pm 32.71$ & $32.69 \pm 15.16$ & 0.20 \\
\hline
\end{tabular}

Values are given as mean \pm standard deviation; $n=$ number of subjects.

Table 2: Serum total cholesterol and high density lipoprotein cholesterol concentration in subjects according to marital status and occupation.

\begin{tabular}{llcccc}
\hline & Subjects & & TC $(\mathbf{m g} / \mathbf{d l})$ & HDL $-\mathbf{C H}(\mathbf{m g} / \mathbf{d l})$ & HDL $-\mathbf{C H} / \mathbf{T C}$ \\
\hline \multirow{3}{*}{ Marital status } & Married & $\mathrm{M}(\mathrm{n}=19)$ & $154.38^{\mathrm{a}} \pm 34.52$ & $28.15 \pm 9.82$ & 0.18 \\
& & $\mathrm{~F}(\mathrm{n}=12)$ & $165.57 \pm 27.6$ & $35.42 \pm 15.17$ & 0.21 \\
& Non Married & $\mathrm{M}(\mathrm{n}=23)$ & $125.58^{\mathrm{a}, \mathrm{b}} \pm 30.45$ & $23.76 \pm 11.76$ & 0.19 \\
Occupation & & $\mathrm{F}(\mathrm{n}=7)$ & $159.79^{\mathrm{b}} \pm 37.10$ & $27.64 \pm 15.18$ & 0117 \\
& Students & $\mathrm{M}(\mathrm{n}=23)$ & $124.30^{\mathrm{c}, \mathrm{d}} \pm 24.06$ & $24.44 \pm 12.75$ & 0.20 \\
& & $\mathrm{~F}(\mathrm{n}=7)$ & $172.47^{\mathrm{c}} \pm 40.33$ & $36.09 \pm 13.119$ & 0.21 \\
& Others & $\mathrm{M}(\mathrm{n}=7)$ & $156.62^{\mathrm{d}} \pm 34.88$ & $26.78 \pm 11.65$ & 0.17 \\
& & $\mathrm{~F}(\mathrm{n}=12)$ & $159.78 \pm 25.67$ & $29.41 \pm 15.89$ & 0.18 \\
\hline
\end{tabular}

Values are given as mean \pm standard deviation $n=$ number of subjects Values bearing similar superscript in the same row are significantly different at $p<0.05$.

\section{DISCUSSION}

The relatively small sample size and nature of the samples employed in this study are a reflection of the difficulties associated with blood sampling in this community. With the women folk, the difficulties assume a greater dimension and therefore female subjects constituted only 31 percent of the total number of subjects studied. In this study, serum TC and $\mathrm{HDL}-\mathrm{CH}$ levels were found to very with marital status and occupation. This variation can be attributed to differences in personal lifestyle and dietary habits of the subjects (Reddy, 2002; Lee et al., 2003; Kerver et al., 2003).

Comparison of the serum TC and $\mathrm{HDL}-\mathrm{CH}$ levels observed in this study (Table 1) with the levels obtained in other parts of Nigeria reveals remarkable differences in the levels of these lipids. In Calabar (Essien et al., 1992) and Nsukka (Ononogbu, 1979), the serum

\section{REFERENCES}

Abdulazeez, A.M., Anigo, M.K. and Nok, A.J. (2008). Serum levels of High density lipoproteins, total cholesterol and sialic acid in students of Ahmadu Bello University, Zaria, Nigeria. Book of Abstracts, $28^{\text {th }}$ Annual Scientific Conference, Nigerian Society of Biochemistry and Molecular Biology, $24^{\text {th }}-26^{\text {th }}$ November, 2008. Usmanu Danfodio University, Sokoto, Nigeria. P 24.

Atiku, M.K., Iliyasu, A., Sen, K.K. and Ubom, G.A. (2001). Cigarette smoking versus blood pressure, body mass index, serum total cholesterol and HDL - Cholesterol levels in hypertensive subjects resident in Kano Metropolis, Nigeria. NISEB Journa/ 1 (3): 249 - 253.

Bachorik, P.S. (1982). Collection of blood samples for lipoprotein analysis. Clin. Chem. 28 (6): 1375 1378.

Essien, E.U., Afia, E.S., Odigwe, G.O. and Akpanabiatu, M. (1992). Lipid profile in selected disease states among Nigerians, Orient Med. J. 4: 48 - 50.

Henry, R., Black, M. and David, E. (2003). Cardiovascular risk factors Am. J. Clin. Nutr. 76: $93-99$.

Kerver, J.M., Eunjang, L.B. and Won, O.S. (2003). Dietary patterns associated with risk factors for cardiovascular disease in healthy adults. Am. J. Clin. Nutr. 78: $1103-110$. total cholesterol and $\mathrm{HDL}-\mathrm{CH}$ levels were higher than the corresponding values recorded in this study for both male and female subjects. Serum levels of HDL cholesterol and total cholesterol levels reported for students in Zaria (Abdulazeez et al., 2008) are close to values obtained in this study. These differences in serum total cholesterol and HDL - cholesterol levels between our subjects and subjects reported in other parts of the country, go further to confirm geographical and ethnic differences in lipid and lipoprotein concentrations (Ononogbu, 1988). A lot of work still remains to be done in establishing the serum lipid and lipoprotein patterns in this community, specifically the influence of body mass index, income, occupation, cigarette smoking and alcohol consumption on the serum lipid and lipoprotein patterns in the community are areas that await further investigation.

Lee, L.M., Sesso, H.D., Oguma, Y. and Paffen barger, R.S. (Jr) (2003). Relative intensity of physical activity and risk of coronary heart disease. Circulation 107: $3109-3113$.

Lopes-Virella, M.F., Stone, P., Ellis, S. and Colwell, J.A. (1977). Cholesterol determination in HDL separated by three different method. Clin. Chem. 23: $882-$ 884.

Ononogbu, I.C. (1979). Serum cholesterol levels in a Nigerian population sample (Nsukka). Experientia 35: 1428 - 1429.

Ononogbu, L. C. (1988). Lipids and Lipoproteins; Chemistry, Methodology, Metabolsim, Biochemical, Biochemical and Physiological Importance. New Africa Publishing Company Ltd Owerri, Nigeria. Pp 77 $-116$.

Reddy, K.S. (2002). Cardiovascular diseases in the developing countries, determinants, dynamics and directions for public health action. Public Health Nutrition 5: $231-237$.

Zlatkis, A., Zak, B. and Boyle, A. J. (1953). A new method for the direct determination of serum cholesterol. $J$. Lab. Clin. Med. 4: 486 - 492. 